anterior ribs by muscular violence in the horse has been recorded by Hockfleth, ${ }^{2}$ and Gabriel ${ }^{2}$ has recorded another case which is, however, of possibly doubtful character. Speaking generally it is to be expecterl that direct violenco will be less likely to fracture the stronger and less curved ribs of a quadruped than the more curved and relatively weaker ribs of man. The greater elasticity of the latter may assist them in some degree. The force will first drive inwards the rib or ribs at the point struck. This may learl to fracture at this point or, if the force is insufficient for this, to temporary bending of the ribs, especially in man. In either case the force, being great enough, miy lead indirectly to the ribs being broken nearer the sternum or vertebral column-i.e., their fixed ends. In the horse this further fracture, owing to the lesser curvature of the ribs. will occur closer to the sternum or vertebral column than in the case of the more strongly curved and elastic ribs of man Ashley ${ }^{3}$ records a very interesting case in which the eighth and ninth ribs of a horse were broken by direct violence applied approximately to their centre, further fractures being found close to the vertebra and sternum. The number of ribs attached to the sternum will therefore influence the secondary fractures occurring near the sternum. The presence of the joint in the ribs of the ungulates will in some slight degree counteract the greater elasticity of man's ribs in the comparison. Goodwin ${ }^{4}$ has also recorded a somewhat similar case in which secondary fractures were found two inches from the vertebral column. And again the force was transmitted by the strong, slightly curved ribs to the vertebræ, resulting in a fracture of one of these. The further or secondary fractures are examples of fracture by indirect violence and may occur with a primary fracture at the point of application of the force or with simple bencling in of the ribs there, the elasticity of the rib in man and to some degree the joint in the ribs of the horse allowing sufficient deformation to occur. 'The ribs of a quadruped may therefore be broken by both direct and indirect violence. In the case of man, probably by far the greater number of ribs fractured by blows are broken by indirect violence, the ribs being only driven in at the place struck, the fracture occurring a little way off. This is perhaps not sufficiently appreciated and explains the comparative absence of injuries to the deeper lying structures such as would be expected frequently to occur from direct violence. In man the presence of a clavicle protects the first two ribs; in horses though this bone is absent the anterior ribs are naturally protected by the position of the fore-limbs. Owing to the greater number of the ribs of horses a greater variety of the deeper lying structures may be exposed or injured, such as the omentum.

In conclusion, I must acknowledge my thanks to Mr. C. M. Goodbody for the diagrams which illustrate this article.

St. Thomas's Hospital, S.E.

\section{A CASE OF CURIOUS GUNSHOT WOUND OF THE HEAD;}

PENETRATION OF THE BRAIN BY AN IRON RAMROD COMPLETE RECOVERY.

BY G. LACY BARRITT, L.R.C.P. LOND., M.R.C.S. ENG., SURGEOX TO THE JOHISTION HOSPITAL, SPALDING.

A Bor, aged fifteen years, was admitted to the Johnston Hospital, Spalding, on July 20th, 1898. This boy was employed scaring crows and was provided with a muzzleloading gun with a roughly made iron ramrod $30 \frac{1}{2}$ in. long and $\frac{5}{8}$ in. in diameter at the bulbous end and weighing

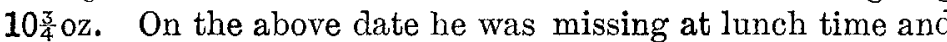
his brother went to look for him ; he found him lying on the ground rubbing his head, with blood on his shirt and coat. On being spoken to he got up and though he appeared to be quite dazed he walked 200 yards to the farmyard carrying his gun. He was bleeding from his forehead and could not be made to speak and it was noticed that he could not use his right hand properly. His head was bandaged by one of

1 Móller's Veterinary Surgery, p. 184.

Veterinarian, vol. xxiî., p. 666.

Journal of Comparative Pathology, vol. xi. 2, p. 175 Veterinarian, vol. iii., p. 681 . the labourers who had attended ambulance classes and he was driven to the hospital, a clistance of three miles. On his arrival he got out of the trap and walked into the ho.ipital.

The putient was seen by me shortly after his aumission. He was lying in becl in a semi-comatose condition; on examination he was found to have a punctured wound of about the size of a sixpence in the forehead 3 in. above the centre of the left eyebrow and another slightly larger wound of a similar character over the centre of the left parietal eminence (Fig. 1). On closcly examining these wounds

Fic. 1.

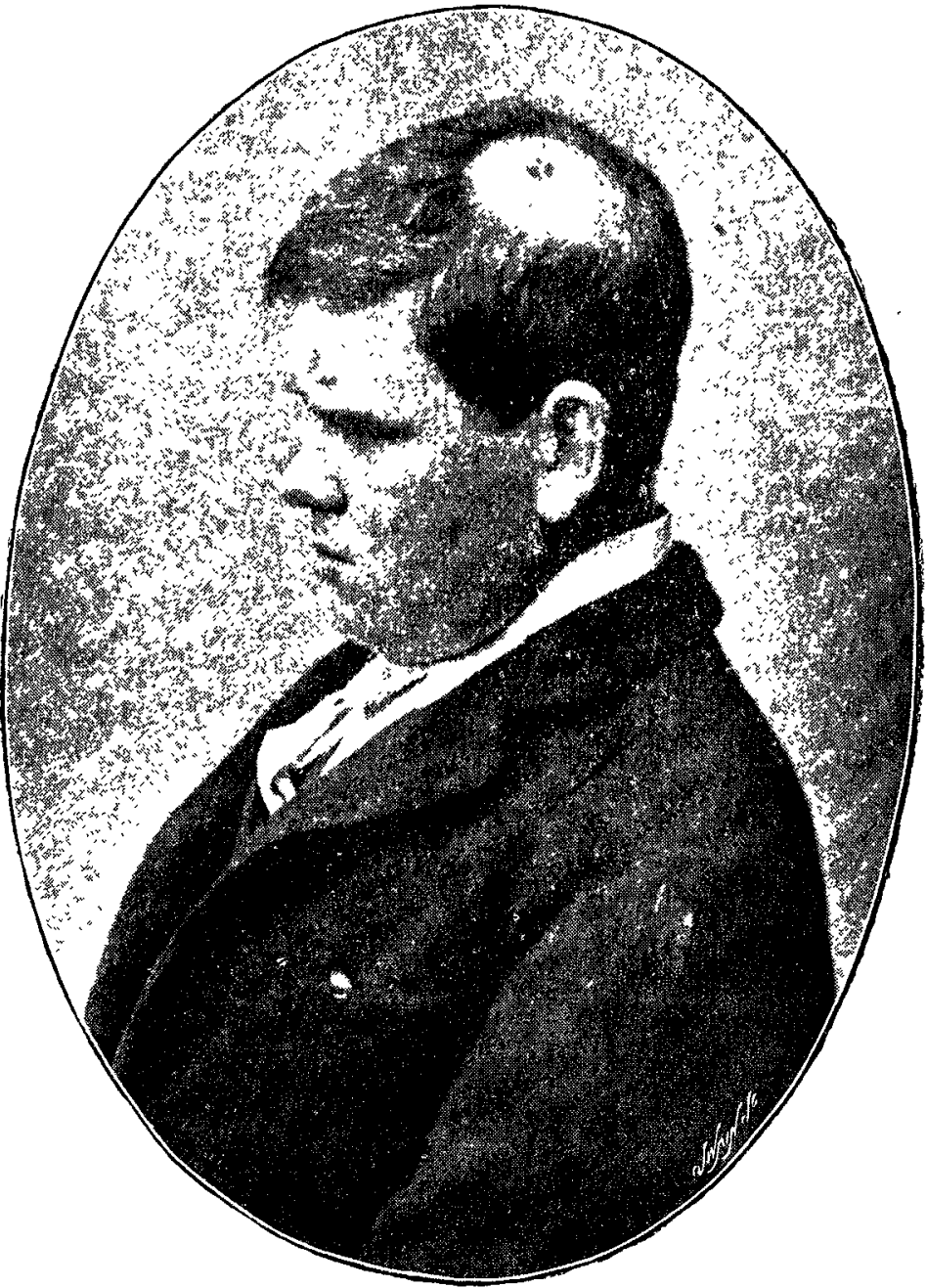

Repronluetion of photograph showing the wounds in the heat.

they were both found to lead directly down to the skull cap, which was fractured in both places, the fractures being clean punched-out holes in the skull, the one over the forehead just admitting the tip of the little finger and the other one being slightly larger and more ragged at the edges. There was no splintering of the bone, the punctures in the skull being as clean almost as if they had been made with a drill. In order to thoroughly ascertain what injury had been done a fine probe was passed gently into each wound and was found to penetrate quite easily right into the interior of the skull for $2 \mathrm{in}$. No attempt was made to pass the probe farther for fear of increasing the mischief, though there is little doubt that the probe might have been passed right through from one wound to the other. The diagnosis was arrived at that some foreign body had penetrated completely through the skull and from the position of the two wounds must have wounded the brain.

On further inquiry and from the subsequent statement of the lad when he recovered it appears that he was loading his gun with the hammer cocked and a cap cn the nipple; the force of the ramming with the heavy iron ramrod jarred the hammer off and the ramrod was driven straight through his head entering above the eyebrow and making its exit at the vault of the skull throngh the wounds clescribed above. The ramrod was found about 14 yards from the spot where he fell with his cap transfixed on it, as shown in Fig. 2.

The patient's temperature was normal and his pulse was slow and regular; there was slight scorching of the face round the wound of entrance; and there was slight oozing of blood from both wounds, more from the wound of entrance than from that of exit. The patient though apparently 
comatose could easily be roused and would answer questions in a dull, hazy manner, his answers, however, being perfectly rational. He could move all his limbs, but it was noticed that the movements of the right arm were clumsy and awkward; the limb was thrown about like a flail, there evidently being partial paralysis of the limb. There was marked dilatation of the left pupil, the right pupil being normal; though both reacted to light the left one was more sluggish than the right. It was decided to use expectant treatment and I had both wounds dressed antiseptically and an ice-bag applied to the head; perfect quiet and a purely milk diet were ordered. I sawithe patient several times during the afternoon but there was no alteration in his condition; on visiting him in the evening, however, I decided to dress the wounds as there had been considerable oozing from the wound in the forehead. On removing the dressing it was seen that several frontal lobe of the brain, where some loss of function might be considered almost certain. No doubt the ramrod passed at a terrific velocity through the skull and brain structure being made entirely of iron and of considerable weight it would cause less destruction of tissue than if the ramrod, as is usual, had been made of wood, as the velocity would have been less, the weight of the iron ramrod adding explosive power to the powder. My friend Mr. Sydney Jones of St. Thomas's Hospital saw this case about six weeks after the accident and pointed out the peculiarly shallow shape of the boy's skull over the frontal eminences; this I think makes the case still more extraordinary as had the ramrod passed entirely through grey matter one would think it must have destroyed some important centre. I think the ramrod penetrated the grey matter at the orifice of entrance and again at that of exit, the seat of the track being through the white substance. The wound must have been very near

FIG. 2.

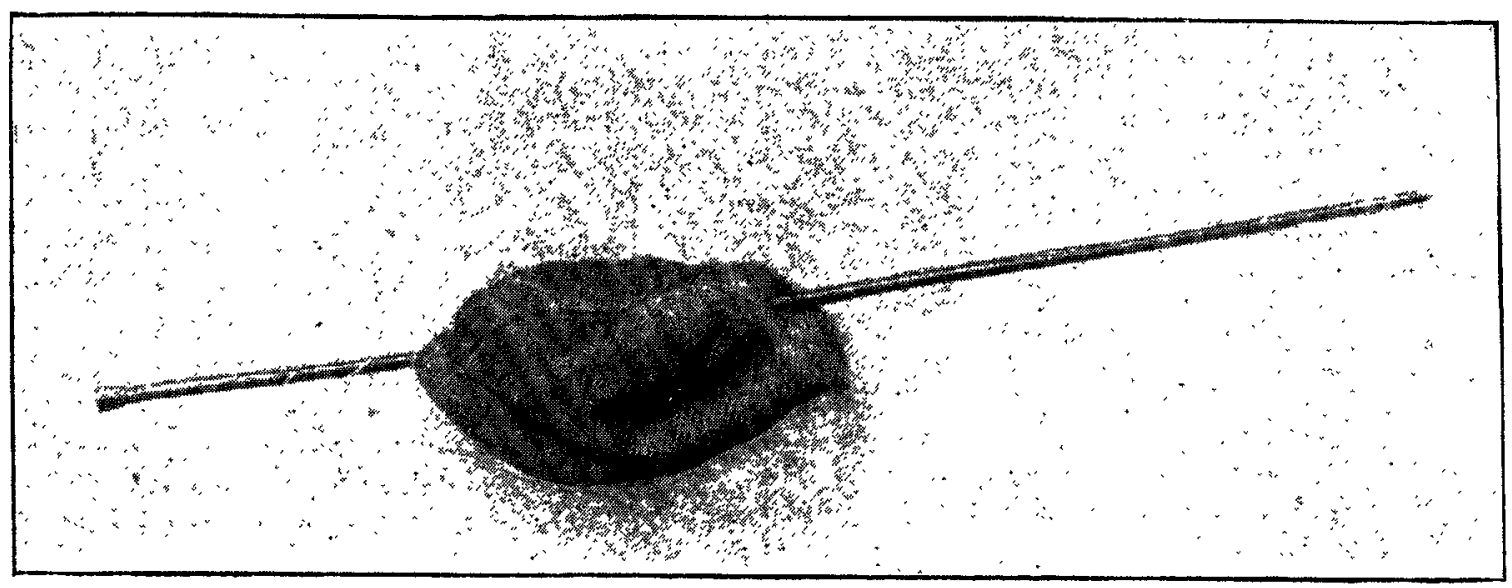

Reproduction of photograph showing the ramrot and cap as they were found.

small nodules of brain substance, varying from the size of a pin's head to that of a pea, had exuded from the wounds, the actual amount being about enough to cover a shilling. The paralysis of the right arm was more marked and the left pupil was more fixed. The patient's temperature was $99 \cdot 2^{\circ} \mathrm{F}$. and his pulse was quiet; he could easily be roused and answered questions quite well. I ordered an enema to be administered which acted satis. factorily. The patient passed a rather restless night and was at times very irritable. The same symptoms continued for four days, the temperature keeping fairly normal, never above $99.4^{\circ}$ except on the second evening when it reached $100^{\circ}$. The paralysis of the arm became more marked though it could still be moved by the patient. The discharge of brain substance did not continue after the second day, the whole amount exuded being not more than of the size of a filbert nut. On the fifth day the patient became more conscious and would answer questions readily and would try to grasp things with his right hand when asked to do so. The same treatment was continued; an enema was administered every other day and the diet was confined entirely to milk. The patient never had any difficulty in passing his urine. From the fifth day the patient daily improved and without exhibiting a single bad symptom made an uninterrupted recovery and after three weeks in bed was allowed up and put on solid food. The paralysis of the arm during this time gradually improved and since has almost entirely disappeared, the patient expressing the condition of it by saying that he felt as if slight power had gone out of it, though he could write almost as well as ever he could. The wounds in the head were slow in healing and three weeks after the injury a small shell of bone of about the size of a split pea exfoliated from the wound of entrance, after which the wound healed perfectly. There is still a small superficial sinus in the wound of exit probably due to a small shell of bone which cannot be detected however with the probe. The patient now seems to be in perfect health and has put on weight since his admission to the hospital. His mental faculties seem quite intact and he has practically perfect use of his arm.

The above case, I take it, clearly shows that the brain can sustain injuries which one would consider to be absolutely fatal and yet will recover without any appreciable detriment to its structure although the parts injured were in the left the centre for speech and also that for the movements of the arm. The speech was never impaired, the wound no doubt being above and internal to the centre; the centre for arm movement was also not touched or it must have been destroyed, the partial paralysis, I presume, being due to pressure from hæmorrhage through the wounded track of brain which must have been very near it; as the hæmorrhage abated the paralysis disappeared. For the most excellent photographs from which the illustrations are reproduced $I$ am indebted to my friend Mr. W. A. Southwell, manager of the Stamford and Spalding Bank, at Spalding.

Spaltling.

\section{VARIETIES AND VIRULENCE OF THE PNEUMOCOCCUS. ${ }^{1}$}

BY J. W. EYRE, M.S., M.D. DURH.,

OPHTHALMIC SURGEON TO ST. MARY'S CHIIDREN'S HOSPITAL, PIAAISTOW SENIOR OPHTHALMIC ASSLSTAN'T TO GUX'S HOSPITAI; AND

J. W. WASHBOURN, M.D., F.R.C.P. LOND.,

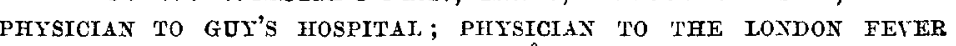
HOSPITAL, \&C.

Thene are a large number of types of the pneumococcus which differ from one another in virulence and in biological characters. At the one end of the scale is the parasitic type - the typical pneumococcus of the text-books. This type leads with difficulty a saprophytic existence; it will only grow at temperatures approaching that of the human body, it will not grow upon media which are faintly acid, and it rapidly dies out when cultivated upon agar or in broth. Rabbits inoculated with this type die from septicæmia and the blood after death is found to be crowded with diplococci. At the other end of the scale is the saprophytic type described by us in a previous paper ${ }^{2}$ which was obtained from a typical pneumococcus by a special method of cultivation. This type grows luxuriantly at $37^{\circ} \mathrm{C}$., and

1 This investigation was aided lyy a grant from the Royal Society.

2 Resistant Forms of the Pneumococcus, Journal of Pathology and Bacteriology, March, 1897 